See discussions, stats, and author profiles for this publication at: https://www.researchgate.net/publication/348732296

\title{
The Effect of Quartet Card Learning on Semantic Memory of SD Unggulan Puri Taman Sari Makassar
}

Conference Paper · October 2016

4 authors, including:

Muhammad Riszky

Universitas Negeri Makassar

4 PUBLICATIONS OCITATIONS

SEE PROFILE 

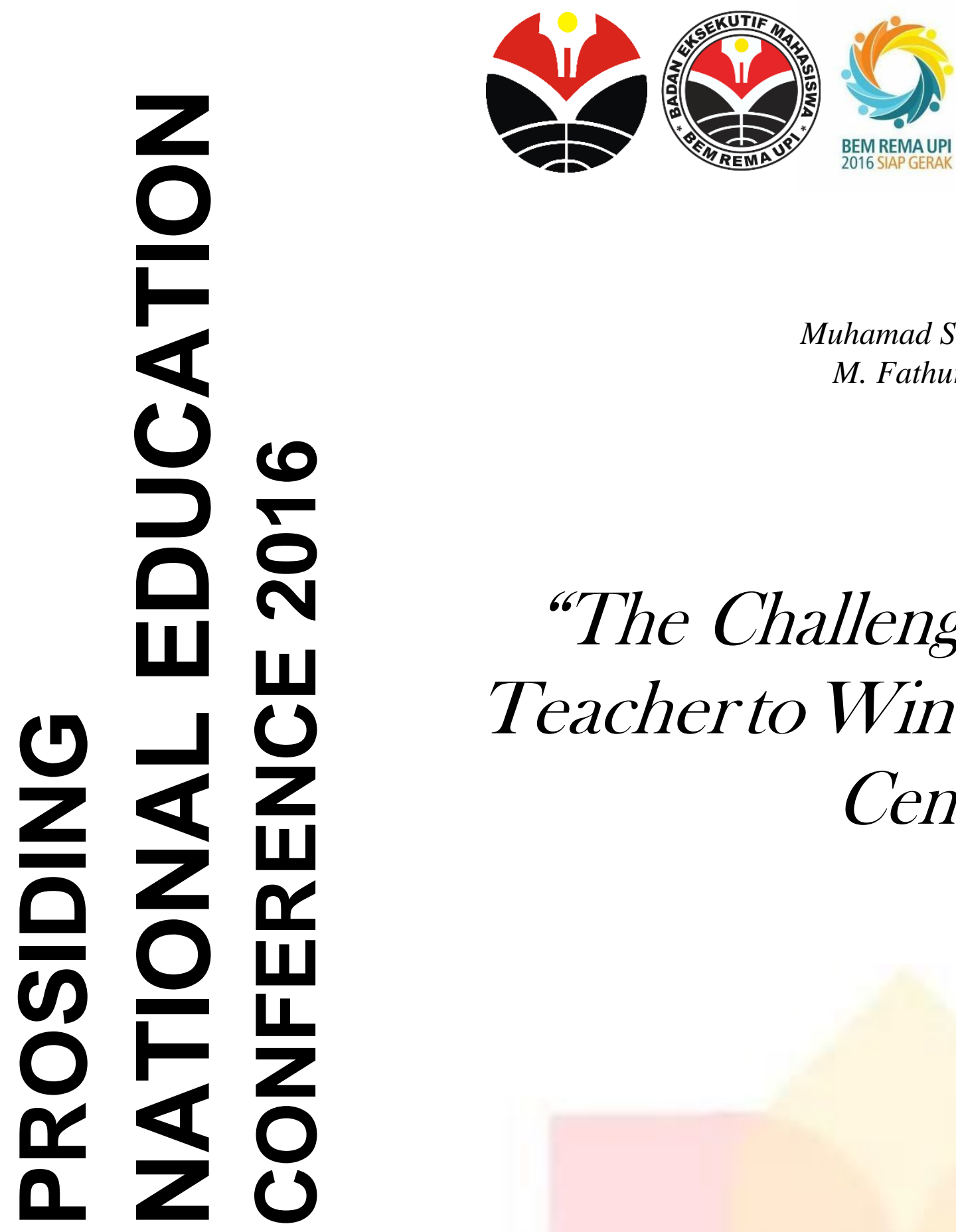

Editor : Muhamad Saepul Akbar M. Fathur Ramadhan Nur Miftah

\section{"The Challenges of Teacherto Win 21th Century"}

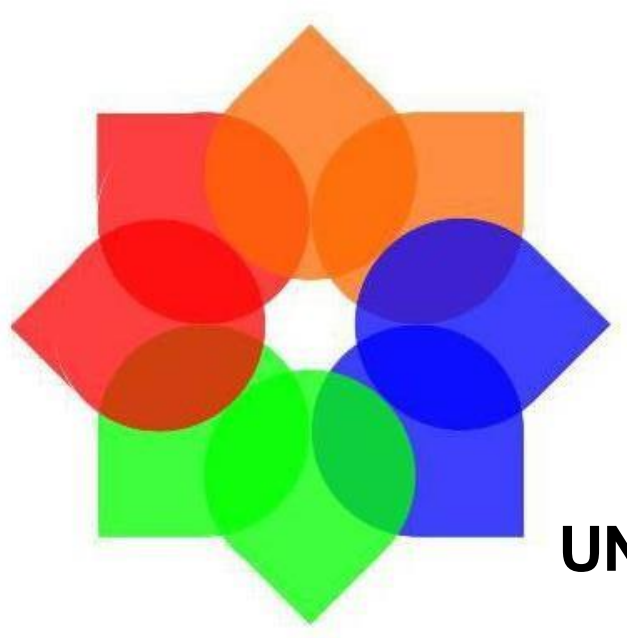




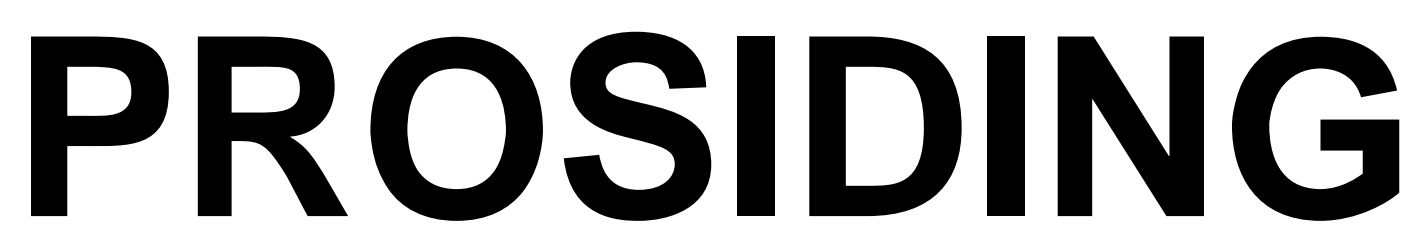

\section{NATIONAL EDUCATION CONFERENCE 2016}

\section{The Challenges of Teacher to Win 21th Century}

Editor :

Muhamad Saepul Akbar

M. Fathur Ramadhan

Nur Miftah

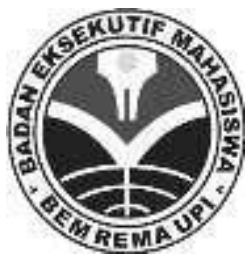




\section{BADAN EKSEKUTIF MAHASISWA \\ REPUBLIK MAHASISWA}

\section{UNIVERSITAS PENDIDIKAN Indonesia PROSIDING NATIONAL \\ EDUCATION CONFERENCE 2016}

The Challenges of Teacher di Win 21th Century

Penulis :

ISBN. 978-602-19191-4-9

Editor :

Muhamad Saepul Akbar

M. Fathur Ramadhan

Nur Miftah

Penyunting :

Fanny Azzahra

Muhamad Saepul Akbar

M. Fathur Ramadhan

Desain sampul dan tata letak

Muhamad Saepul Akbar

Penerbit :

Badan Eksekutif Mahasiswa Republik Mahasiswa

Redaksi :

Universitas Pendidikan Indonesia

Jl. Dr. Setiabudhi No. 229 Bandung 40154

Telp. 022-2013163

Cetakan pertama,

Hak cipta dilindungi undang-undang

Dilarang memperbanyak karya tulis ini dalam bentuk dan dengan cara apa pun tanpa ijin tertulis dari penerbit 


\title{
PENGARUH MEDIA PEMBELAJARAN KARTU KUARTET TERHADAP MEMORI SEMANTIK SISWA SD UNGGULAN PURI TAMAN SARI MAKASSAR
}

\author{
Muhammad Riszky ${ }^{1)}$, Mutmainnah Nur Rahmah ${ }^{2)}$, Adlia Julia Sari ${ }^{3)}$, \\ Ismi Shahriani Silmi ${ }^{4}$ \\ 1) ,2), 3), 4) Fakultas Psikologi \\ Universitas Negeri Makassar \\ Email : muhammadriszky@yahoo.co.id
}

\begin{abstract}
ABSTRAK
Penelitian ini bertujuan untuk menunjukkan pemberian media pembelajaran kartu kuartet mempengaruhi memori semantik siswa sekolah dasar (SD) dengan menggunakan dua variabel, variabel bebas yaitu media pembelajaran kartu kuartet dan variabel terikat yaitu memori semantik. Isi dari materinya yaitu berisi mengenai budaya yang ada di Sulawesi Selatan yang dibagi menjadi delapan aspek terdiri dari pahlawan, tempat wisata, kuliner, pakaian adat, alat musik, rumah adat, permainan, dan seni tari. Rancangan penelitian ini merupakan eksperimen dengan menggunakan rancangan randomized two group design. Partisipan dalam penelitian ini terdiri dari 24 siswa kelas 4 SD yang dibagi menjadi dua kelompok yang terdiri dari kelompok eksperimen yang menggunakan media pembelajaran kartu kuartet dan kelompok kontrol yang menggunakan metode ceramah. Penggunaan media pembelajaran kartu kuartet memiliki pengaruh lebih besar dalam memori semantik dibandingkan dengan memori ceramah. Berdasarkan uji statistic melalui SPSS, diperoleh skor rata-rata kelompok eksperimen sebesar 12.750 dan skor rata-rata kelompok kontrol sebesar 8.166. Berdasarkan uji independent sample $t$-test melalui SPSS diperoleh nilai $p=0.000$. Nilai $p<0.050$ menunjukkan bahwa hasil signifikan dan hipotesis diterima, maka terdapat perbedaan memori semantik antara kelompok individu yang menggunakan media pembelajaran kartu kuartet dibandingkan metode ceramah. Penelitian ini menyimpulkan bahwa kegiatan dengan menggunakan metode pembelajaran kartu kuartet dapat meningkatkan hasil belajar siswa dibandingkan dengan metode pembelajaran ceramah.
\end{abstract}

Kata Kunci: budaya, kartu kuartet, media pembelajaran, memori semantik

\begin{abstract}
The purpose of this study is to show media learning kuartet card will showing an influence semantic memory student's in elementary school. This study using two variabel's, independent is media learning kuartet card and dependent is semantic memory. This research design is an experiment with randomized two group design. The participants in this study were 24 students in four grade in elementary school, the student's divided into two groups, the experimental group using media learning kuartet card and control group using lecture method. Media learning kuartet card have greater influence in semantic memory than lecture method. The result of statistic test in SPSS, an average score of the experimental group is 12.750 and an average score of the control group is 8.166. The result by independent sample t-test in SPSS showed a $\mathrm{p}=0.000$. $\mathrm{p}<0.050$ showed a significance and the hypothesis is accepted, so there is
\end{abstract}


a difference in semantic memory student's between media learning kuartet card and lecture method.

Keywords: culture, kuartet card, media of learning, semantic memory

\section{PENDAHULUAN}

Memori merupakan salah satu hal penting dalam kehidupan manusia sehingga fungsinya fundamental dalam kinerja intelektual. Memori telah menuntun perilaku manusia baik secara sadar maupun tidak sadar. Memori secara sadar menuntun manusia dalam mengingat seperti waktu, tujuan dan arah serta berbagai informasi penting lainnya. Myers (2010:327) mengemukakan bahwa memori merupakan proses belajar yang dilakukan dari waktu ke waktu dapat disimpan dan dipanggil kembali. Saat individu mendapatkan pengalaman baru maka individu akan menyimpan pengalaman pada memori. Ketika individu membutuhkan pengalaman yang telah disimpan maka individu dapat memanggil kembali pengalaman yang telah ada.

Untuk dapat melakukan kerja tersebut, memori berjalan berdasarkan suatu sistem yang berkelanjutan. Dalam sistem ini terdapat tiga tahap yang saling berkaitan. Tahap pertama, adalah tahap di mana memori memasukkan kode maupun pesan ke dalam ingatan. Proses ini sering disebut sebagai proses encoding. Pada tahap yang kedua dikenal sebagai proses storage atau fungsi penyimpanan. Pada tahap ketiga memori mengambil data, kode maupun pesan yang telah disimpan atau yang lebih dikenal dengan proses retrevial. Prosesproses tersebut berjalan dengan koordinasi sistem psikis dan fisik manusia Atkinson, et al (Widjayanti \& Setiyawati, 2009). Salah satu dari memori tersebut ialah memori semantik.
Tulving (Solso, Maclin \& Maclin, 2007) mengungkapkan bahwa memori semantik adalah jenis memori yang melibatkan pengetahuan umum, konsep, dan fakta-fakta tentang dunia atau ide, kata, konsep, dan peraturan-peraturan.ingatan semantik merupakan pengetahuan mengenai segala sesuatu yang menyangkut karakteristik yang berdasarkan pada Daftar Pustaka kognitif. Pentingnya memori sebagai salah satu faktor psikis kehidupan, maka seyogyanya manusia mengoptimalkan fungsi-fungsi memorinya untuk tetap menjalankan rutinitas kehidupan, Salah satunya pada proses pembelajaran.

Tulving dan Craick (Sternberg, 2008) mengungkapkan bahwa seluruh informasi hasil belajar seseorang akan tersimpan di dalam memori untuk digunakan pada waktu selanjutnya. Suatu informasi dapat menjadi bagian dari memori apabila terjadi perubahan fungsional dan struktural secara menetap pada otak. Strategi belajar yang sesuai dengan prinsip-prinsip penyandian memori yaitu dengan menggunakan media.

Penggunaan media pembelajaran bertujuan untuk membangkitkan minat dan menstimulasi kreativitas siswa dalam mengingat pelajaran yang telah didapatkan.

Hal tersebut sesuai yang dikemukakan Hamalik (Arsyad, 2007) mengungkapkan bahwa pemakaian media pembelajaran dalam proses belajar mengajar dapat membangkitkan keinginan dan minat yang baru, membangkitkan motivasi dan rangsangan kegiatan pembelajaran.

Apabila media membawa pesan atau 
informasi yang bertujuan secara instruksional serta mengandung maksudmaksud pengajaran maka media itu disebut sebagai media pembelajaran. Menurut Kulsum (2013) bahwa dengan menggunakan media pembelajaran diharapkan siswa akan dapat memperoleh berbagai pengalaman nyata, sehingga materi pelajaran yang disampaikan dapat diserap dengan mudah dan lebih baik. Siswa merupakan individu yang sedang berkembang secara fisik dan intelektual. Salah satu media pembelajaran yang dapat digunakan untuk meningkatkan memori semantik pada siswa yaitu melalui kartu kuartet.

Peneliti ini menunjukkan bahwa pemberian media pembelajaran kartu kuartet mempengaruhi memori semantik siswa SD. Hipotesis dalam penelitian ini adalah terdapat perbedaan memori semantik antara kelompok individu yang menggunakan media pembelajaran kartu kuartet dibandingkan metode ceramah.

\section{METODE PENELITIAN}

\section{A. Variabel}

Penelitian ini menggunakan dua variabel, variabel bebas yaitu media pembelajaran kartu kuartet dan variabel terikat yaitu memori semantik. Isi dari materinya yaitu berisi mengenai budaya yang ada di Sulawesi Selatan yang dibagi menjadi delapan aspek terdiri dari pahlawan, tempat wisata, kuliner, pakaian adat, alat musik, rumah adat, permainan, dan seni tari.

B. Partisipan

Partisipan adalah 24 orang siswa kelas 4 SD Unggulan Puri Taman Sari Makassar yang terdiri dari 12 perempuan dan 12 lakilaki. Penentuan partisipan dilakukan dengan memberikan pengumuman kepada Kepala Sekolah dan Wali Kelas. Wali Kelas kemudian memberikan nama-nama siswa yang bersedia menjadi partisipan. Partisipan dibagi menjadi dua kelompok, yaitu kelompok eksperimen dan kontrol dengan cara menggunakan teknik simple random sampling.

C. Desain

Rancangan penelitian yang dilakukan adalah eksperimen dengan dengan menggunakan rancangan randomized two group design. Desain tersebut membuat dua kondisi yang berbeda dengan kelompok eksperimen diberi perlakuan sedangkan kelompok kontrok tidak diberi perlakuan. Duan kelompok ini kemudian dibandingkan.

\begin{tabular}{|c|c|c|c|c|}
\hline Assignment & Kelompok & Pretest & Perlakuan & Posttest \\
\hline R & KE & - & X & O \\
\hline & KK & - & - & O \\
\hline
\end{tabular}

Tabel 1. Rancangan Penelitian

D. Manipulasi

Untuk menguji hipotesis partisipan dibagi menjadi dua kelompok yang terdiri dari kelompok yang menggunakan media pembelajaran kartu kuartet dengan kelompok kontrol yang menggunakan 
metode ceramah. Pembagian kelompok dilakukan dengan cara berhitung " 1 " dan "2" setelah semua partisipan terkumpul. Bagi partisipan yang mendapatkan angka 1 $(n=12)$ menggunakan media pembelajaran kartu kuartet dan partisipan yang mendapatkan angka $2(n=12)$ menggunakan metode ceramah.

Pada kelompok eksperimen diberikan kartu kuartet sebagai media pembelajaran. Kartu kuartet berisi mengenai budaya Sulawesi Selatan yang terdapat penjelasan pada setiap kartunya. Kartu kuartet dimainkan oleh 4 orang siswa sehingga dibagi menjadi tiga kelompok. Setiap kelompok diberikan masing-masing dua kali kesempatan bermain. Tiap kelompok didampingi satu orang yang bertugas untuk melihat dan memberikan penjelasan bila terdapat pertanyaan dari siswa. Pada kelompok kontrol siswa diberikan metode ceramah dengan materi yang sama yaitu budaya Sulawesi Selatan. Pemberian materi dilakukan sebanyak satu orang peneliti.

Masing-masing dua kelompok tersebut yang menyelesaikan materinya diberikan tes yakni Tes Melengkapi (Completion Test). Tujuannya yakni untuk mengukur memori partisipan yang terdiri dari 15 soal.

E. Pengumpulan Data

Data yang diperoleh dari Tes Melengkapi di scoring dimana setiap jawaban benar diberi skor satu dan setiap jawaban yang salah diberi skor nol. Setelah scoring, kemudian diukur dengan menggunakan IBM SPSS Statistic 22.

F. Prosedur

Tahap-tahap dalam penelitian ini yaitu: (1) membagi partisipan dalam dua kelompok (2) peneliti memberikan materi yang telah disusun (3) setelah diberikan materi, peneliti menguji memori semantik partisipan dengan memberikan tes melengkapi yang terdiri dari 15 soal.

\section{HASIL DAN PEMBAHASAN}

Penggunaan media pembelajaran memengaruhi memori semantik siswa SD Puri Taman Sari Makassar. Penggunaan media pembelajaran kartu kuartet memiliki pengaruh lebih besar dalam memori semantik dibandingkan dengan memori ceramah. Hal tersebut dapat dilihat dari rata-rata skor partisipan penelitian.

\begin{tabular}{|c|c|c|c|}
\hline Kelompok & $\mathrm{N}$ & Mean & SD \\
\hline Eksperimen & 12 & 12.750 & 2.598 \\
\hline Kontrol & 12 & 8.166 & 1.585 \\
\hline Tabel 2. Deskripsi Hasil Tes
\end{tabular}

Berdasarkan uji statistic melalui SPSS, diperoleh skor rata-rata kelompok eksperimen sebesar 12.750 dan skor ratarata kelompok kontrol sebesar 8.166.

Analisis data dalam penelitian ini menggunakan uji t. Uji t dilakukan dengan asumsi bahwa sampel memiliki distribusi normal dan bersifat homogen.

a. Uji normalitas

Uji normalitas dalam penelitian dilakukan dengan menggunakan metode Kolmogorov-Smirnov.

\begin{tabular}{lcc} 
Kelompok & \multicolumn{2}{c}{ Kolmogorov-Smirnov } \\
Statistic & Sig. \\
Eksperimen & .205 & .175 \\
Kontrol & .200 & .198
\end{tabular}

Tabel 3. Uji Normalitas

Berdasarkan uji Kolmogorov-Smirnov melalui SPSS diperoleh nilai $p>0.050$ (kelompok eksperimen $p=0.175$; dan kelompok kontrol $p=0.198$ ). Nilai $p>0.050$ menunjukkan bahwa data penelitian berada dalam distribusi normal.

b. Uji homogenitas

Uji homogenitas dalam penelitian 
dilakukan dengan menggunakan metode Levene's Test.

\begin{tabular}{|c|c|c|c|}
\hline $\begin{array}{c}\text { Levene } \\
\text { Statistic }\end{array}$ & df1 & df2 & Sig. \\
\hline 1.801 & 1 & 22 & .193 \\
\hline \multicolumn{2}{|c|}{ Tabel } & 4. & Uji Homogenitas
\end{tabular}

Berdasarkan uji Levene's Test melalui SPSS diperoleh nilai $p=0.193$. Nilai $p>0.050$ menunjukkan bahwa variansi sampel penelitian bersifat homogen.

c. Uji Hipotesis

Uji hipotesis dalam penelitian menggunakan independent sample t-test.

$\begin{array}{lll}\text { thitung } & \text { Df } & \text { Sig. } \\ 5.216 & 22 & .000\end{array}$

Tabel 5. Uji Hipotesis

Berdasarkan uji independent sample t-test melalui SPSS diperoleh nilai $p=0.000$. Nilai $p<0.050$ menunjukkan bahwa hasil signifikan dan hipotesis diterima, sehingga terdapat perbedaan memori semantik antara kelompok individu yang menggunakan media pembelajaran kartu kuartet dibandingkan metode ceramah.

Berdasarkan hasil penelitian yang telah dilakukan yang dilihat dari hasil analisis deskripsi menunjukkan bahwa kelompok individu yang menggunakan metode pembelajaran melalui permainan kartu kuartet memiliki nilai rata-rata yang lebih tinggi dibandingkan dengan kelompok individu yang menggunakan metode pembelajaran ceramah. Padmono (2011:142) mengemukakan bahwa kelebihan metode permainan adalah dapat digunakan untuk memberikan pengalaman menarik bagi siswa dalam memahami suatu konsep, dapat menguatkan konsep yang telah dipahami, dan dapat menguatkan konsep yang telah dipahami, dan dapat mengembangkan motivasi intrinsik. Saefudin, Dhamayanti, Suhartono, dan Wahyudi (2013:54) mengemukakan bahwa penggunaan metode permainan pada pembelajaran Bahasa Inggris dapat meningkatkan hasil belajar siswa.

\section{KESIMPULAN}

Penelitian ini menyimpulkan bahwa kegiatan dengan menggunakan metode pembelajaran kartu kuartet dapat meningkatkan hasil belajar siswa dengan meningkatkan memori semantik siswa dibandingkan dengan metode pembelajaran ceramah. kelompok yang menggunakan metode kuartet lebih memahami dan mengingat materi yang ada dalam kartu dibandingkan dengan kelompok individu dengan metode ceramah.

\section{DAFTAR PUSTAKA}

Arsyad, A. (2007). Media pembelajaran.

Jakarta: Raja Grafindo Persada.

Kulsum, R.U. (2013). Penggunaan

permainan edukatif sebagai media belajar efektif bagi guru PAI SD. Dikutip dari:

http://bdkjakarta.kemenag.go.id/index. php? $\mathrm{a}=$ artikel\&id $=853$.

Myers, D. G. (2010). Psychology (9 $9^{\text {th }}$ ed.). USA: Worth Publishers.

Padmono, Y. 2011. Manajemen pembelajaran di kelas. Salatiga: Widya Sari Press.

Saefudin, A., Dhamayanti, Y., Suhartono., \& Wahyudi. (2013). Penerapan metode menggunakan kartu kosakata dalam pembelajaran bahasa inggris siswa kelas V SD. Jurnal Pendidikan. 13(4), 52-60.

Solso, R.L., Maclin, O.H., \& Maclin, M.K. (2007). Psikologi kognitif ( $8^{\text {th }}$ ed). Jakarta: Erlangga.

Sternberg, R.J. (2008). Psikologi kognitif $\left(8^{\text {th }}\right.$ ed). Yogyakarta: Pustaka Belajar.

Widjayanti, I. P \& Setiyawati, D. (2009). Memori implisit dan memori eksplisit pada penderita diabetes mellitus dan non diabetes mellitus. Jurnal Psikologi, 2(2), 127-140. 

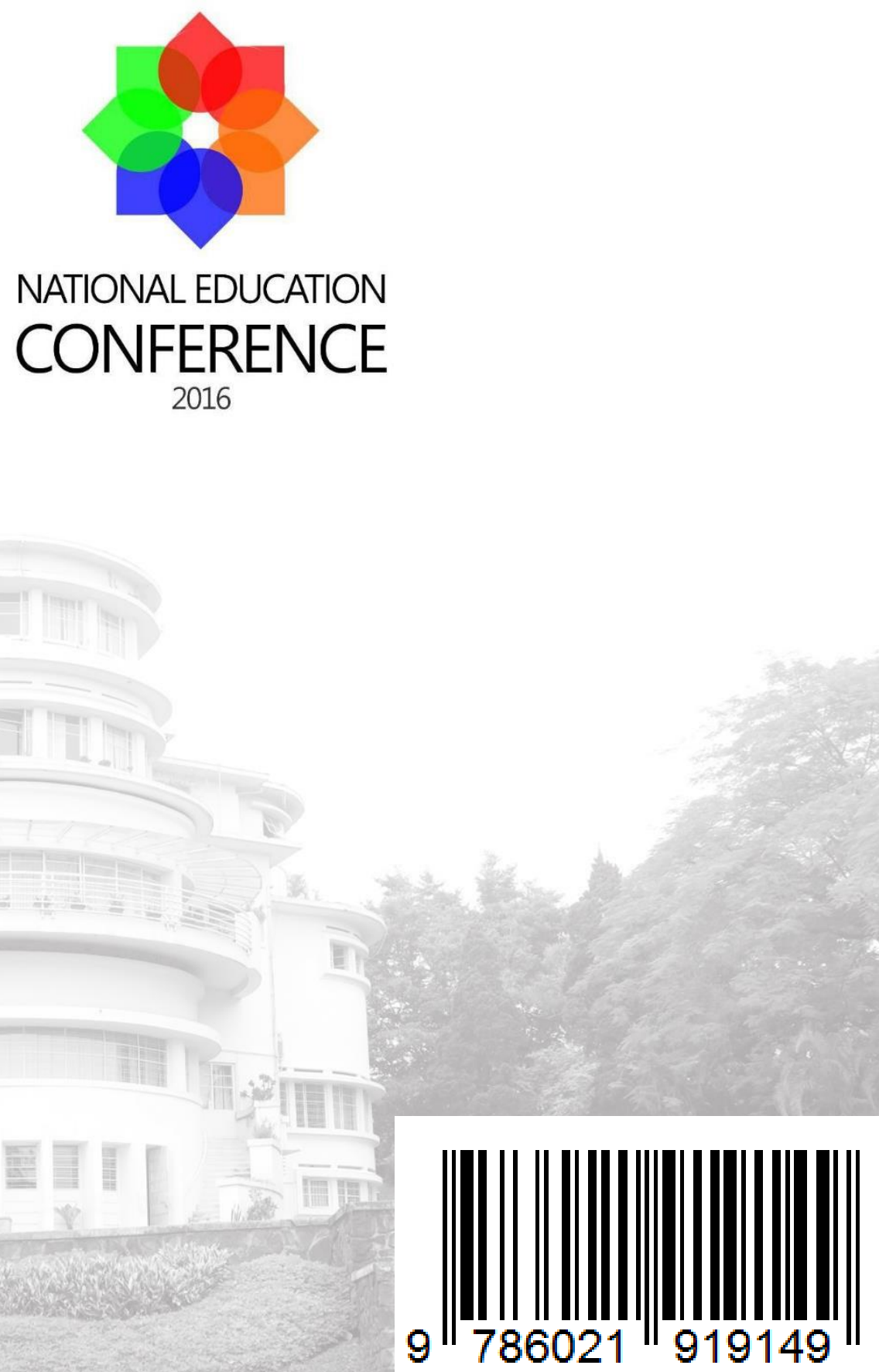

ISBN. 978-602-19191-4-9 